\title{
NORMATIVNO I STRATEGIJSKO- -DOKTRINARNO UREĐENJE UPOTREBE VOJSKE SRBIJE U ZAŠTITI I SPASAVANJU U VANREDNIM SITUACIJAMA
}

\author{
Hajradin Radončić \\ Univerzitet odbrane u Beogradu, Škola nacionalne odbrane \\ Sabahudin Coković \\ Univerzitet EDUCONS u Sremskoj Kamenici, \\ Fakultet za studije bezbednosti
} vanrednim situacijama. Težište je usmereno na sistem zaštite i spasavanja i zakonske i strategijsko doktrinarne pretpostavke.

Kroz analizu normativno i strategijsko-doktrinarnih dokumenata, upotrebe Vojske Srbije u zaštiti i spasavanju u vanrednim situacijama, ponudiće se moguća rešenja za otklanjanje slabosti koje neposredno proizlaze iz normativno i strategijsko-doktrinarnih dokumenata sistema zaštite i spasavanja.

Ključne reči: Vojska Srbije, vanredne situacije, zaštita i spasavanja

\section{Uvod}

S ve češće elementarne nepogode na teritoriji Republike Srbije su realnost. Kada su pretnje ozbiljne, a materijalna razaranja velika, organi civilne vlasti, nadležne službe i druge organizacije, otklanjaju nastale posledice uz učešće Vojske Srbije. Otklanjanje prethodno navedenih posledica elementarnih nepogoda danas je bez upotrebe Vojske nezamislivo.

Napomenućemo da Vojska Srbije poseduje određene kapacitete i sposobnosti, koji se po odluci nadležnih državnih organa a u skladu sa pozitivnim pravnim aktima Republike Srbije, Ustavom Republike Srbije, Zakonom o vanrednim situacijama, Zakonom o odbrani Republike Srbije, kao i strategijskim i doktrinarnim rešenjima Vojska Srbije može se upotrebiti radi pomoći civilnim vlastima u slučaju prirodnih nepogoda.

Vojska Srbije može se angažovati u podršci civilnim vlastima i stanovništvu radi zaštite i spasavanja ljudi, materijalnih i kulturnih dobara od elementarnih nepogoda, tehničkotehnoloških nesreća i katastrofa, posledica terorizma i drugih većih nesreća izvršavajući zadatke trće misije. Vojska Srbije ne razvija posebne snage namenjene za pružanje podrške civilnim vlastima, već angažuje postojeće koje, shodno svojoj osnovnoj nameni, izvršavaju ove zadatke. Kako angažovanje Vojske Srbije je regulisano kroz više normativno i strategijsko doktrinarnim dokumentima potrebno je bilo sa aspekta nauke izvršiti komparativnu analizi i ukazati na eventualnu neusaglašenost dokumenata radi doprinosa 
upotrebe Vojske Srbije u zaštiti i spasavanju u vanrednim situacijama. Za uspeh u izvršavanju misija i zadataka Vojske Srbije od velikog značaja je usklađenost normativno i strategijsko doktrinarnih dokumenata koja uređuju upotrebu Vojske Srbije u zaštiti i spasavanju u vanrednim situacijama koja su i predmet ovog rada.

\section{Prikaz stanja elementarnih nepogoda i drugih stanja opasnosti}

U nacionalnoj strategiji zaštite i spasavanja u vanrednim situacijama, istaknuto je da teritorija Republike Srbije iznosi $88.361 \mathrm{~km}^{2}$ sa 6.164 naseljena mesta i $9.351 .298^{1}$ stanovnikom po popisu iz 2011. godine. Na ovom prostoru u poslednjih sedam godina bilo je ukupno 175.083 raznih događaja od čega 134.686 požara, 13.620 tehničkih intervencija (spasavanja ljudi u saobraćajnim i drugim tehničko tehnološkim nezgodama, intervenisanje i saniranje akcidenata sa opasnim materijama i drugih nezgoda). Podaci ukazuju na rast intervencija (tabela broj 1). Neophodno je napomenuti da su aktivnosti vatrogasno-spasilačkih jedinica usmerene u $77 \%$ slučajeva na aktivnosti gašenje požara i saniranja posledica nastalih nakon eksplozija, a u 20,5\% slučajeva aktivnosti su usmerene na spasavanju građana i njihovih dobara u ostalim intervencijama. ${ }^{2}$

Tabela 1 - Prikaz stanja elementarnih nepogoda i drugih stanja opasnosti ${ }^{3}$

\begin{tabular}{|l|r|r|r|r|r|r|r|r|}
\hline \multicolumn{1}{|c|}{$\begin{array}{c}\text { Vrsta } \\
\text { događaja }\end{array}$} & 2002. & 2003. & 2004. & 2005. & 2006. & 2007. & 2008. & 2009. \\
\hline Požar & 14.841 & 19.271 & 15.061 & 14.670 & 17.847 & 28.546 & 24.450 & 21.545 \\
\hline Eksplozija & 25 & 42 & 36 & 32 & 39 & 35 & 43 & 44 \\
\hline $\begin{array}{l}\text { Tehničke } \\
\text { intervencije }\end{array}$ & 877 & 990 & 1.144 & 1.214 & 1.318 & 1.640 & 1.515 & 1.706 \\
\hline $\begin{array}{l}\text { Tehničke } \\
\text { intervencije sa } \\
\text { opasnim } \\
\text { materijama }\end{array}$ & 43 & 71 & 64 & 80 & 78 & 60 & 69 & 84 \\
\hline $\begin{array}{l}\text { Tehničke } \\
\text { intervencije u } \\
\text { saobraćaju }\end{array}$ & 411 & 510 & 608 & 638 & 709 & 819 & 742 & 784 \\
\hline
\end{tabular}

Srpska ekonomija, usled posledica prirodnih katastrofa, trpi značajne gubitke u materijalnim dobrima, a atmosferske nepogode prouzrokuju gubitke i u ljudskim životima. Procenjene štete u vremensko zavisnim sektorima u Republici Srbiji, date su u tabeli 1.

\footnotetext{
${ }^{1}$ Popisu stanovništva Republičkog zavoda za statistiku Republike Srbije dodati su podaci za KiM Komiteta UN za demografska istraživanja (podaci UMPROFOR-a) za 2011.

${ }^{2}$ Nacionalna strategija zaštite i spasavanja u vanrednim situacijama (Sl. glasnik Republike Srbije, br. 86/1), str. 16.

${ }^{3}$ Isto.
} 
Tabela 2 - Procenjene štete u vremensko zavisnim sektorima ${ }^{4}$

\begin{tabular}{|c|c|c|}
\hline \multirow{2}{*}{ Sektor/nepovoljne vremenske pojave } & \multicolumn{2}{|c|}{ Procena gubitaka u sektorima } \\
\hline & $\begin{array}{l}\text { Srednji godišnji ekonomski } \\
\text { gubici u milionima dinara }\end{array}$ & $\begin{array}{l}\text { Srednji godišnji gubici } \\
\text { ljudskih života }\end{array}$ \\
\hline Poljoprivreda/poplave & Od 3.100 do 8.500 & Nekoliko do desetine \\
\hline Vodoprivreda/poplave & Oko 1.960 & - \\
\hline $\begin{array}{l}\text { Poljoprivreda/grad, jake i obilne padavine, } \\
\text { jak vetar }\end{array}$ & Oko 7.316 & $\begin{array}{l}\text { Nekoliko do desetine i to od } \\
\text { udara groma }\end{array}$ \\
\hline Poljoprivreda/ suša, mrazevi & Oko 4.0000 & Nema gubitaka \\
\hline $\begin{array}{l}\text { Proizvodnja energije (toplotna energija)/ } \\
\text { ekstremno niske temperature vazduha }\end{array}$ & Oko 716 & Nekoliko do desetine \\
\hline $\begin{array}{l}\text { Održavanje puteva/sneg, poledica, } \\
\text { zaleđivanje }\end{array}$ & Oko 3.500 & - \\
\hline \multicolumn{3}{|c|}{$\begin{array}{l}\text { Ljudski gubici na autoputevima, regionalnim i lokalnim putevima prouzrokovani lošim vremenom } \\
\text { godišnje se kreću od } 105 \text { do } 131\end{array}$} \\
\hline Komercijalni vazdušni saobraćaj & Od 54 do 72 & - \\
\hline UKUPNO & Od 16.648 do 48.572 & Od nekoliko do 160 \\
\hline
\end{tabular}

Poplavama u Srbiji je potencijalno je ugroženo $10.968 \mathrm{~km}^{2}$, što zahvata $12,4 \%$ teritorije. Najveće poplavne površine su u dolini Tise, Save, Velike Morave i Dunava. U dolinama Save i Dunava, poplave su predisponirane padavinama, ali i koincidencijom poplavnih talasa njihovih pritoka. ${ }^{5}$ Dolina Velike Morave je vodoplavna celokupnom svojom dužinom. Najveću širinu poplavne površine dostižu na sektoru između ušća Resave i ušća Velike Morave. Druga ugrožena zona je Paraćinsko-jagodinska kotlina. Velike poplavne površine nalaze se i u dolinama većih pritoka Južne Morave. U slivu Zapadne Morave, karakteristična mesta pogodna za poplave su najniži delovi Čačanske i Kraljevačke kotline, kao i dolina donjeg toka Zapadne Morave, nizvodno od Trstenika. ${ }^{6}$

$\mathrm{U}$ cilju preventivnog delovanja urađena je procena ugroženosti teritorije Republike Srbije od poplava i klizanja terena, i na osnovu raspoloživih statističkih podataka urađena je karta rizika od elementarnih nepogoda (šumski požari, poplave, klizišta i zemljotresi) što je značajan korak institucija Republike Srbije u preventivnom delovanju, kao to da procena ugroženosti Republike Srbije od poplava i klizanja terena i karta rizika od elementarnih nepogoda je od izuzetne značajnosti za izradu normativnih i strategijsko doktrinarnih dokumenata koja uređuju upotrebu Vojske Srbije u zaštiti i spasavanju u vanrednim situacijama.

\footnotetext{
${ }^{4}$ Isto, str. 16.

${ }^{5}$ Milanović A. i dr.: Poplave u Srbiji u periodu 1999-2009. godina - hidrološka analiza i mere zaštite od poplava, Glasnik srpskog geografskog društva, sveska 90, Beograd, 2010, str. 93.

${ }^{6}$ Vuruna M. i dr: Zaštita životne sredine, Medija centar "Odbrana", Beograd, 2012, str. 102.
} 


\section{Normativno uređenje upotrebe Vojske Srbije u zaštiti i spasavanju u vanrednim situacijama}

Normativno utemeljenje zaštite i spasavanja uslovljeno je definisanjem preciznih nadležnosti i procedura na svim nivoima organizovanja, shodno kojima su subjekti zaštite i spasavanja dužni da se ponašaju. Normativno uređenje sistema zaštite i spasavanja predstavlja uslov da subjekti zaštite i spasavanja ostvaruju svoju ulogu u celini sistema zaštite i spasavanja i pravnog sistema države.

Sistem zaštite i spasavanja koncipiran je tako da postoji definisana struktura i način funkcionisanja, sa jasno određenim zadacima a koji su propisani u najvišem opštem pravnom aktu Republike Srbije, Ustavu Republike Srbije, Zakonu o vanrednim situacijama, Zakonu o odbrani i Vojsci Srbije.

Ustav Republike Srbije ${ }^{\dagger}$, kao najviši opšti pravni akt u članu 1. precizira da je Republika Srbija država srpskog naroda i svih građana koji u njoj žive, zasnovana na vladavini prava i socijalnoj pravdi, načelima građanske demokratije, ljudskim i manjinskim pravima i slobodama i pripadnosti evropskim principima i vrednostima. Članom 97. Ustava Republike Srbije utvrđena je nadležnost Republike Srbije da uređuje i obezbeđuje: nezavisnost, ustavnost, teritorijalnu celovitost i bezbednost Republike Srbije, njen međunarodni položaj i odnose sa drugim državama i međunarodnim organizacijama; ostvarivanje i zaštitu sloboda i prava građana, ustavnost i zakonitost, odbranu i bezbednost države i njenih građana, mere za slučaj vanrednog stanja; sistem prelaska granica i kontrole prometa roba; zaštitu na radu; održivi razvoj, sistem zaštite i unapređenja životne sredine, kao i ostale oblasti i odnose od interesa za Republiku Srbiju u skladu sa Ustavom. Članovima 188-190. propisana je nadležnost lokalnih samouprava. Saglasno navedenim članovima Ustava, opštine su u obavezi da se preko svojih organa: staraju o zaštiti životne sredine, zaštiti od elementarnih i drugih nepogoda; zaštiti kulturnih dobara od značaja za opštinu. Članom 200. i članom 201. Ustava Republike Srbije, u zavisnosti od stepena opasnosti po bezbednost Republike Srbije može biti proglašeno vanredno i ratno stanje. Vanredno stanje ${ }^{8}$ predstavlja poseban režim koje proglašava Narodna skupština Republike Srbije. Ratno stanje proglašava Narodna skupština Republike Srbije, a kad Narodna skupština nije u mogućnosti da se sastane - odluku o proglašenju ratnog stanja donose zajedno predsednik Republike, predsednik Narodne skupštine i predsednik Vlade, a to predstavlja situacije kada je Srbija u neposrednoj ratnoj opasnosti, kada joj je objavljen rat ili je napadnuta.

Zakon o vanrednim situacijama ${ }^{9}$ uređuje: delovanje, proglašavanje i upravljanje u vanrednim situacijama; sistem zaštite i spasavanja ljudi, materijalnih i kulturnih dobara i životne sredine od elementarnih nepogoda, tehničko-tehnoloških nesreća - udesa i katastrofa, posledica terorizma, ratnih i drugih većih nesreća; nadležnosti državnih organa, autonomnih pokrajina, jedinica lokalne samouprave i učešće policije i Vojske Srbije u za-

\footnotetext{
${ }^{7}$ Ustav Republike Srbije (SI. glasnik Republike Srbije, br. 98/2006).

${ }^{8}$ Prema Zakonu o merama u slučaju vanrednog stanja (SI. glasnik Republike Srbije, br 19/91), vanredno stanje se proglašava ako dođe do unutrašnjih nemira (nereda) većih razmera, u kojima se nasiljem i drugim protivpravnim oblicima delovanja ugrožava ustavni poredak; ako nastupe prirodne i druge nesreće koje u velikim razmerama ugrožavaju živote građana i njihovu imovinu i materijalna dobra zemlje.

${ }^{9}$ Zakon o vanrednim situacijama (Sl. glasnik Republike Srbije br. 111/2009, 92/2011 i 93/2012).
} 
štiti i spasavanju; prava i dužnosti građana, privrednih društava, drugih pravnih lica i preduzetnika u vezi sa vanrednim situacijama; organizaciju i delatnost civilne zaštite na zaštiti, spasavanju i otklanjanju posledica elementarnih nepogoda i drugih nesreća;

Zakon o odbrani Republike Srbije ${ }^{10}$ u glavi VII, od članova 77 do 80 . reguliše civilnu zaštitu. Članom 77. Zakona o odbrani Republike Srbije, Civilna zaštita se organizuje, priprema i sprovodi kao sistem zaštite i spasavanja ljudi, životinja, materijalnih i kulturnih dobara od elementarnih nepogoda, tehničko-tehnoloških nesreća i katastrofa, posledica terorizma, ratnih i drugih većih nesreća, a u skladu s važećim propisima, načelima i zahtevima Dopunskog protokola uz Ženevske konvencije i drugim pravilima međunarodnog humanitarnog prava, kao i potvrđenim međunarodnim ugovorima.

Nadležnosti Vojske Srbije ${ }^{11}$ regulisane su članovima 30 do 41. gde se navodi da Vojska Srbije brani zemlju od oružanog ugrožavanja spolja i izvršava druge misije i zadatke, u skladu s Ustavom, zakonom i principima međunarodnog prava koji regulišu upotrebu sile. U slučaju prirodnih i drugih nesreća većih razmera u kojima su na određenoj teritoriji ugroženi život i zdravlje ljudi i životinja i materijalna dobra, jedinice Vojske Srbije, na zahtev organa nadležnih za zaštitu i spasavanje ljudi i materijalnih dobara, mogu se angažovati na pružanju pomoći stanovništvu, u skladu s posebnim zakonom. Članom 46 definisane su nadležnosti načelnika generalštaba Vojske Srbije, gde se navod da načelnik generalštaba Vojske Srbije, odnosno starešina nadležne komande Vojske Srbije, na osnovu posebnog ovlašćenja predsednika Republike, a radi zaštite i spasavanja ljudi, materijalnih i kulturnih dobara od elementarnih nepogoda, tehničko-tehnoloških nesreća i katastrofa, posledica terorizma i drugih većih nesreća, može narediti mere sprovođenja pripravnosti i upotrebu delova Vojske Srbije, radi otklanjanja štetnih posledica koje mogu nastati nevojnim pretnjama bezbednosti.

Iz navedenog može se zaključiti da je normativno uređenje u Republici Srbiji uređeno i omogućavaju angažovanje Vojske Srbije u zaštiti i spasavanju u vanrednim situacijama, i time obezbeđuje ostvarivanje nacionalnih interesa u oblasti bezbednosti, koji su izraz vitalnih vrednosti i potreba građana, naroda i države i proizilaze iz najviših vrednosti koje su utvrđene Ustavom Republike Srbije u sprečavanju delatnosti kojima se ugrožava životi i imovina građana Republike Srbije.

\section{Strategijsko uređenje upotrebe Vojske Srbije u zaštiti i spasavanju u vanrednim situacijama}

Strategija nacionalne bezbednosti ${ }^{12}$ predstavlja najvažniji strateški dokument kojim se utvrđuju osnove politike bezbednosti u zaštiti nacionalnih interesa Republike Srbije. Strategija nacionalne bezbednosti daje analizu okruženja Srbije; identifikuje izazove, rizike i pretnje bezbednosti; utvrđuje nacionalne interese; određuje ciljeve, osnovna načela i elemente politike nacionalne bezbednosti i definiše strukturu, načela funkcionisanja i od-

\footnotetext{
${ }^{10}$ Zakon o odbrani Republike Srbije (Sl. glasnik Republike Srbije, br. 116/2007, 88/2009, 88/2009 - dr. zakon, 104/2009 - dr. zakon i 10/2015).

${ }^{11}$ Isto, član 30-46.

${ }^{12}$ Strategija nacionalne bezbednosti Republike Srbije (SI. glasnik Republike Srbije, br. 88/2009).
} 
govornosti u okviru sistema bezbednosti i predstavlja osnov za izradu strategijskih dokumenata u svim oblastima društvenog života i funkcionisanja državnih organa i institucija, radi očuvanja i zaštite bezbednosti građana, društva i države.

Pitanje izazovi, rizici i pretnje bezbednosti Republike Srbije, među navedenim jeste pitanje posledice elementarnih nepogoda i tehničkih i tehnoloških nesreća, kao i ugrožavanje životne sredine i zdravlja građana usled radiološke, hemijske i biološke kontaminacije, stalni su bezbednosni rizici za Republiku Srbiju, njeno stanovništvo i materijalna dobra. Gde ukazuje da značajan rizik predstavljaju tehnološke nesreće u kojima efekti dejstva opasnih materija mogu zahvatiti ne samo teritoriju Republike Srbije već i susedne države. Životnu sredinu dodatno ugrožavaju i objekti sa visokim stepenom rizika u zemljama regiona, kao i privredni objekti sa tehnologijom koja ne zadovoljava međunarodne ekološke standarde navodi se u Strategiju nacionalne bezbednosti.

U Strategiji nacionalne bezbednosti posebno je istaknuto da ona predstavlja osnov za izradu strategijskih dokumenata u svim oblastima društvenog života i funkcionisanja državnih organa i institucija, radi očuvanja i zaštite bezbednosti građana, društva i države. ${ }^{13}$

Strategija odbrane Republike Srbije ${ }^{14}$ predstavlja osnovni strateški dokument kojim se usmerava angažovanje resursa odbrane i razvoj normativnih, doktrinarnih i organizacijskih rešenja sistema odbrane Republike Srbije. U Strategiji odbrane se analizira bezbednosno okruženje; identifikuju izazovi, rizici i pretnje odbrani; ${ }^{15}$ utvrđuju odbrambeni interesi i politika odbrane Republike Srbije; koncipira sistem odbrane i utvrđuju osnovna opredeljenja o planiranju i finansiranju odbrane.

Poseban deo pri analizi sadržaja Strategija odbrane Republike Srbije pored izazovi, rizici i pretnje jeste predmet ovog rada i sistem odbrane Republike Srbije. Sistem odbrane Republike Srbije deo sistema nacionalne bezbednosti i predstavlja jedinstvenu, strukturno uređenu i funkcionalnu celinu snaga i subjekata odbrane čiji je cilj zaštita odbrambenih interesa Republike Srbije. Zaštita odbrambenih interesa je jedinstvena funkcija države i realizuje se kroz vojnu i civilnu odbranu. Nosilac vojne odbrane je Vojska Srbije, a u ostvarivanju civilne odbrane angažuju se državni organi, organi državne uprave, organi autonomnih pokrajina, organi jedinica lokalne samouprave, privredna društva, javne službe i ostali subjekti i snage sistema odbrane. ${ }^{16}$

U Strategiji odbrane je istaknuto da misije i zadatke Vojske definiše Narodna skupština Republike Srbije u skladu sa ustavom i na osnovu neotuđivog prava Republike Srbije na individualnu i kolektivnu odbranu, saglasno članu 51. Povelje UN i osnovnim principima međunarodnog prava koji reguliše upotrebu sile. ${ }^{17}$ Misije i zadatke Vojske Srbije ${ }^{18}$ i misije i zadatke civilne odbrane ${ }^{19}$ definiše Strategija odbrane.

\footnotetext{
${ }^{13}$ Isto, str. 33.

${ }^{14}$ Strategija odbrane Republike Srbije (SI. glasnik Republike Srbije, br. 116/07).

${ }^{15}$ Gde se ukazuje na elementarne nepogode i hemijske, biološke, nuklearne, tehničke i tehnološke nesreće da su stalna bezbednosna pretnja za Republiku Srbiju, njeno stanovništvo, materijalna dobra i životnu sredinu. Negativne posledice ovih pojava mogu da zahvate i ugroze teritorije susednih država, a isto tako se mogu sa teritorija susednih država proširiti na Republiku Srbiju i ugroziti njenu teritoriju i stanovništvo.

${ }^{16}$ Strategija odbrane Republike Srbije (SI. glasnik Republike Srbije, br. 116/07).

${ }^{17}$ Isto, str. 11.

${ }^{18}$ Misije Vojske Srbije su: 1) odbrana Republike Srbije od oružanog ugrožavanja spolja, 2) učešće u izgradnji i očuvanju mira u regionu i svetu, i podrška civilnim vlastima u suprotstavljanju pretnjama bezbednosti. Dodeljene misije Vojska Srbije realizuje izvršavanjem zadataka. Odbrana Republike Srbije od oružanog ugrožavanja spolja
} 
U Strategiji odbrane se navodi da je civilna odbrana deo jedinstvenog sistema odbrane. Posebno se definiše da upravljanje i rukovođenje civilnom odbranom i drugim subjektima značajnim za odbranu deo je jedinstvenog upravljanja sistemom odbrane i sprovodi se u okviru državnih organa, organa državne uprave, organa autonomnih pokrajina, organa jedinica lokalne samouprave, privrednih društava i drugih pravnih lica, u skladu sa zakonom. ${ }^{20}$

Sa aspekta bezbednosti Republike Srbije može se uočiti pitanje planiranja odbrane. Planiranje odbrane ima primarni značaj u procesu upravljanja sistemom odbrane. Sistem planiranja odbrane obezbeđuje izgradnju potrebnih sposobnosti, funkcionisanje i razvoj sistema odbrane, racionalno angažovanje raspoloživih resursa odbrane i transparentnost raspolaganja finansijskim sredstvima za potrebe odbrane. ${ }^{21}$

Planiranje odbrane ostvaruje se kroz izradu strategijsko-doktrinarnih dokumenata, planove i programe razvoja sistema odbrane i planiranje upotrebe snaga. Što, upravo i jeste jedno od pitanja ovog rada strategijsko doktrinarno uređenje upotrebe Vojske Srbije u zaštiti i spasavanju u vanrednim situacijama.

Imajući u vidu prikaz stanja elementarnih nepogoda i drugih stanja opasnosti (Tabela 1 i 2) kao i izazove, rizike i pretnje iskazane u Strategiji nacionalne bezbednosti i Strategije odbrane Republike Srbije može se zaključiti da elementarne nepogode i tehničke i tehnološke nesreće predstavljaju pretnju koja ugrožava živote i imovinu građana Republike Srbije i time ugrožava ostvarivanje nacionalnih interesa u oblasti bezbednosti i vitalnih odbrambenih interesa Republike Srbije.

Nacionalna strategija za zaštitu i spasavanje, ${ }^{22}$ osnov za donošenje Nacionalne strategije sadržan je u Zakonu o vanrednim situacijama („Službeni glasnik RS“, broj 111/09) kojim je definisano uspostavljanje integrisanog sistema zaštite i spasavanja. Pored zakonodavnog okvira, osnov za izradu Nacionalne strategije sadržan je i u drugim nacionalnim i međunarodnim do-

realizuje se kroz odvraćanje od oružanog ugrožavanja, odbranu teritorije i odbranu vazdušnog prostora. Učešće u izgradnji i očuvanju mira u regionu i svetu realizuje se učešćem u međunarodnoj vojnoj saradnji i učešćem u multinacionalnim operacijama. Podrška civilnim vlastima u suprotstavljanju pretnjama bezbednosti realizuje se kroz pomoć civilnim vlastima u suprotstavljanju unutrašnjem ugrožavanju bezbednosti, terorizmu, separatizmu i organizovanom kriminalu i kroz pomoć civilnim vlastima u slučaju prirodnih nepogoda i tehničkih i tehnoloških i drugih nesreća. Vojska obavlja i druge zadatke, na osnovu odluke Narodne skupštine Republike Srbije.

${ }^{19}$ Misije civilne odbrane su: 1) obezbeđivanje pretpostavki za funkcionisanje sistema odbrane, 2) zaštita i spasavanje, i 3) učešće u međunarodnim operacijama zaštite i spasavanja. Obezbeđivanje pretpostavki za funkcionisanje sistema odbrane realizuje se kroz sledeće zadatke: pripremu državnih organa, organa državne uprave, organa autonomnih pokrajina, organa jedinica lokalne samouprave, privrednih društava i drugih pravnih lica za funkcionisanje u miru i u ratnom i vanrednom stanju; obezbeđivanje uslova za život i rad građana u miru i u ratnom i vanrednom stanju; obrazovanje i odbrambeno osposobljavanje građana i koordinaciju aktivnosti sa ostalim institucijama značajnim za odbranu. Zaštita i spasavanje realizuju se kroz osmatranje i obaveštavanje, zaštitu i spasavanje ljudi, zaštitu i sklanjanje materijalnih dobara i očuvanje životne sredine. Nosioci realizacije zadataka zaštite i spasavanja su snage civilne zaštite. U aktivnostima zaštite i spasavanja angažuju se i jedinice Vojske Srbije pod uslovima propisanim zakonom. Učešće u međunarodnim operacijama zaštite i spasavanja ostvaruje se na osnovu međunarodnih I biletaralnih ugovora i sporazuma, kao i u skladu sa ukazanom potrebom za otklanjanje posledica prirodnih i tehničkih i tehnoloških katastrofa. Civilna odbrana realizuje i druge zadatke na osnovu odluka zakonodavnih i izvršnih organa vlasti Republike Srbije, autonomnih pokrajina i jedinica lokalne samouprave.

${ }^{20}$ Strategija odbrane Republike Srbije (SI. glasnik Republike Srbije, br. 116/07).

${ }^{21}$ Isto, str. 14

${ }^{22}$ Nacionalna strategija za zaštitu i spasavanje (SI. glasnik Republike Srbije, br. 86/11 od 18.11.2011). 
kumentima, kao što su: Nacionalni program za integraciju Republike Srbije u Evropsku uniju, Nacionalna strategija održivog razvoja, Strategija nacionalne bezbednosti Republike Srbije, Milenijumski ciljevi razvoja, koje su definisale članice Ujedinjenih nacija i Hjogo okvir za delovanje 2005-2015: Razvoj otpornosti nacija i zajednica na katastrofe. Osim navedenih, prilikom izrade Nacionalne strategije u obzir su uzete Strategija unutrašnje bezbednosti Evropske unije i Strategija Evropske unije za podršku smanjenju rizika od katastrofa u zemljama u razvoju. ${ }^{23}$

Nacionalnom strategijom je definisana vizija ${ }^{24}$ i misija. ${ }^{25}$ Poseban akcenta dat je na strateške oblasti (5). 1) Obezbediti da smanjenje rizika od katastrofa postane nacionalni i lokalni prioritet sa jakom institucionalnom osnovom za sprovođenje; 2) Identifikovati, procenjivati i pratiti rizike i poboljšati rano upozoravanje; 3) koristiti znanje, inovacije i obrazovanje u cilju izgradnje kulture bezbednosti i otpornosti na svim nivoima; 4) Umanjiti faktore rizika; 5) Pripremiti se za slučaj katastrofe radi efikasnog (hitnog) reagovanja na svim nivoima ${ }^{26} \mathrm{U}$ okviru strateških oblasti definisani su strateški ciljevi koji će biti detaljno razrađeni u Akcionom planu.

U delu ANEKS - Oblast vanrednih situacija u Republici Srbiji, u Poglavlju Organizacija, upravljanje i procedure, de se navodi da saglasno Zakonu o vanrednim situacijama za odgovor na vanrednu situaciju odgovorne su snage zaštite i spasavanja koje čine štabovi za vanredne situacije, jedinice civilne zaštite, vatrogasno-spasilačke jedinice, policija, Vojska Srbije i drugi subjekti čija je redovna delatnost zaštita i spasavanje ili koji su opremljeni i osposobljeni za ovakvo reagovanje. Takođe, navodi se da u slučaju proglašenja vanredne situacije usled prirodnih i drugih nesreća i katastrofa, delovi Vojske Srbije mogu biti stavljeni u pripravnost i upotrebljeni po odluci načelnika Generalštaba Vojske Srbije ili nadležnog starešine, a po posebnom ovlašćenju predsednika Republike. ${ }^{27}$

U delu Resursi, navodi se da Ministarstvo odbrane i Vojska Srbije ne razvijaju posebne kapacitete za angažovanje na izvršenju zadataka zaštite i spasavanja, već u slučaju potrebe postojećim kapacitetima vrše podršku civilnim vlastima i nosiocima poslova zaštite i spasavanja. U poslovima zaštite i spasavanja iz Ministarstva odbrane i Vojske Srbije mogu se angažovati kapaciteti logističke podrške, vazduhoplovne, inženjerski sastavi i jedinica $A B H O{ }^{28}$

U delu poglavlja Obuka i Saradnja, uglavnom se odnosi na edukovanje i obučavanje pripadnika profesionalnih i dobrovoljnih vatrogasno-spasilačkih jedinica, kao i građane koji učestvuju u civilnoj zaštiti i strani državljani, u skladu sa propisima, uz odgovarajuću naknadu utvrđenu bilateralnim ili multilateralnim ugovorima. ${ }^{29} \mathrm{U}$ okviru saradnje ističe se Konvencije o prekograničnom efektu industrijskih udesa, Republika Srbija sprovodi saradnju sa Ekonomskom komisijom Ujedinjenih nacija za Evropu (UNECE). ${ }^{30}$

\footnotetext{
${ }^{23}$ Isto, str. 1.

${ }^{24}$ Vizija - razvijen, sveobuhvatan, efikasan i efektivan sistem za smanjenje rizika i posledica od elementarnih nepogoda i drugih nesreća integrisanim upravljanjem vanrednim situacijama u Republici Srbiji kojim se doprinosi povećanju bezbednosti i održivom razvoju u regionu.

${ }^{25}$ Misija - stvaranje uslova za izgradnju društva otpornog na katastrofe razvojem integrisanog i efikasnog sistema za zaštitu i spasavanje u Republici Srbiji do 2016. godine.

${ }^{26}$ Isto.

${ }^{27}$ Isto, str. 14

${ }^{28}$ Isto, str. 16

${ }^{29}$ Isto, str. 18

${ }^{30}$ Isto, str. 19
} 
Pored navedenih u Republici Srbiji donet je set zakona, uredbi, strategija o vanrednim situacijama i zaštite od požara. To su: Zakon o zaštiti od požara, ${ }^{31}$ Zakon o otklanjanju posledica poplava u Republici Srbiji, ${ }^{32}$ Zakon o odbrani od grada, ${ }^{33}$ Zakon o potvrđivanju Sporazuma između Vlade Republike Srbije i Vlade Ruske Federacije o osnivanju Srpsko-Ruskog humanitarnog centra, ${ }^{34}$ Zakon o potvrđivanju Sporazuma između Vlade Republike Srbije i Vlade Slovačke Republike o saradnji i uzajamnoj pomoći u vanrednim situacijama, ${ }^{35}$ Uredba o sprovođenju evakuacije, ${ }^{36}$ Uredba o sadržaju i načinu izrade planova zaštite i spasavanja u vanrednim situacijama, Uredba o obaveznim sredstvima i opremi za ličnu, uzajamnu i kolektivnu zaštitu od elementarnih nepogoda i drugih nesreća, ${ }^{37}$ Uredba o sastavu i načinu rada štabova za vanredne situacije, ${ }^{38}$ Uredba o načinu angažovanja stvari za potrebe zaštite i spasavanja i načinu ostvarivanja prava na naknadu za korišćenje istih, ${ }^{39}$ Uredba o razvrstavanju objekta, delatnosti i zemljišta u kategorije ugroženosti od požara, ${ }^{40}$ Pravilnik o organizaciji i načinu upotrebe specijalizovanih jedinica civilne zaštite ${ }^{41}$ Pravilnik o sadržaju informacija o opasnostima, merama i postupcima u slučaju udesa, ${ }^{42}$ Pravilnik o načinu izrade i sadržaju plana zaštite od udesa, ${ }^{43}$ Pravilnik o vrstama i količinama opasnih materija, objektima i drugim kriterijumima na osnovu kojih se sačinjava Plan zaštite od udesa i preduzimaju mere za sprečavanje udesa i ograničavanje uticaja udesa na život i zdravlje ljudi, materijalna dobra i životnu sredinu, ${ }^{44}$ Pravilnik o organizovanju zaštite od požara prema kategoriji ugroženosti od požara, ${ }^{45}$ Pravilnik 0 minimalnom broju vatrogasaca i tehničkoj opremi i obučenosti profesionalnih vatrogasnih

${ }^{31}$ Zakon o zaštiti od požara (SI. glasnik Republike Srbije, br. 111/2009, 20/2015).

${ }^{32}$ Zakon o otklanjanju posledica poplava u Republici Srbiji (SI. glasnik Republike Srbije, br. 64/2015).

${ }^{33}$ Zakon o odbrani od grada (SI. glasnik Republike Srbije, br. 54/2015).

${ }^{34}$ Zakon o potvrđivanju Sporazuma između Vlade Republike Srbije i Vlade Ruske Federacije o osnivanju Srpsko-Ruskog humanitarnog centra (Sl. glasnik Republike Srbije-međunarodni ugovori, br. 6/2012).

${ }^{35}$ Zakon o potvrđivanju Sporazuma između Vlade Republike Srbije i Vlade Slovačke Republike o saradnji i uzajamnoj pomoći u vanrednim situacijama (SI. Glasnik Republike Srbije-međunarodni ugovori, br. 1/2012).

${ }^{36}$ Uredba o sprovođenju evakuacije (SI. glasnik Republike Srbije, br. 22/2011).

${ }^{37}$ Uredba o sadržaju i načinu izrade planova zaštite i spasavanja u vanrednim situacijama (SI. glasnik Republike Srbije, br. 8/2011).

${ }^{38}$ Uredba o sastavu i načinu rada štabova za vanredne situacije (SI. glasnik Republike Srbije, br. 98/2010).

${ }^{39}$ Uredba o načinu angažovanja stvari za potrebe zaštite i spasavanja i načinu ostvarivanja prava na naknadu za korišćenje istih (SI. glasnik Republike Srbije, br. 10/2013).

${ }^{40}$ Uredba o razvrstavanju objekta, delatnosti i zemljišta u kategorije ugroženosti od požara (SI. glasnik Republike Srbije, br. 76/2010).

${ }^{41}$ Pravilnik o organizaciji i načinu upotrebe specijalizovanih jedinica civilne zaštite (SI. glasnik Republike Srbije, br. 26/2011).

${ }^{42}$ Pravilnik o sadržaju informacija o opasnostima, merama i postupcima u slučaju udesa (SI. glasnik Republike Srbije, br. 18/2012).

${ }^{43}$ Pravilnik o načinu izrade i sadržaju plana zaštite od udesa (SI. glasnik Republike Srbije, br. 82/2012).

${ }^{44}$ Pravilnik o vrstama i količinama opasnih materija, objektima i drugim kriterijumima na osnovu kojih se sačinjava Plan zaštite od udesa i preduzimaju mere za sprečavanje udesa i ograničavanje uticaja udesa na život i zdravlje ljudi, materijalna dobra i životnu sredinu (SI. glasnik Republike Srbije, br. 8/2013).

${ }^{45}$ Pravilnik o organizovanju zaštite od požara prema kategoriji ugroženosti od požara (SI. glasnik Republike Srbije, br. 92/2011). 
jedinica, ${ }^{46}$ Pravilnik o uslovima koje moraju ispunjavati pravna lica registrovana za izvođenje posebne obuke za lica koja rade na poslovima zaštite od požara, ${ }^{47}$ Pravilnik o sadržaju evidencije, načinu njihovog vođenja i periodičnosti pregleda pravnih lica svih kategorija ugroženosti od požara, ${ }^{48}$ Odluka o određivanju ovlašćenih i osposobljenih pravnih lica za zaštitu i spasavanje u Republici Srbiji, ${ }^{49}$ Odluka o osnivanju Budžetskog fonda za vanredne situacije. ${ }^{50}$

Pored navedenih propisa Narodna skupština Republike Srbije donela je i više strategija od značaja za oblast vanrednih situacija: Nacionalna strategija zaštite i spasavanja u vanrednim situacijama, ${ }^{51}$ Strategija zaštite od požara za period od 2012. do 2017. godine. ${ }^{52}$

Iz navedenog može se zaključiti da osnov za donošenje Nacionalne strategije za zaštitu i spasavanje ${ }^{53}$ sadržan je u Zakonu o vanrednim situacijama ("Službeni glasnik RS", broj 111/09), a u okviru saradnje ističe se Konvencije o prekograničnom efektu industrijskih udesa, a ne i u saglasnosti sa Ustavom Republike Srbije, ${ }^{54}$ Zakonom o odbrani Republike Srbije, ${ }^{55}$ Strategijom nacionalne bezbednosti ${ }^{56}$ i Strategijom odbrane Republike Srbije. ${ }^{57}$

\section{Doktrinarno opredeljenje upotrebe Vojske Srbije u zaštiti i spasavanju u vanrednim situacijama}

Elementarne nepogode kao pretnja bezbednosti Republike Srbije su pojava koja danas sve veće izražene u većem obimu po vremenu i prostoru i kao takve pored uobičajenih snaga, zahteva stalnu upotrebu jedinica Vojske Srbije u pružanju pomoći civilnim organima vlasti. Način i uslovi pod kojima se Vojska Srbije angažuje u podršci civilnim vlastima u suprotstavljanju pretnjama bezbednosti definisani su u doktrinarnim dokumentima.

Doktrina Vojske Srbije, je najviši doktrinarni dokument Vojske Srbije, koja daje odgovor kako će Srbija upotrebiti svoje snage u odgovoru na savremene izazove, rizike i pretnje bezbednosti. Pored pitanja kojima se bavi Doktrina, organizovanju, pripremama, upotrebi i obezbeđenju Vojske Srbije u miru, ratnom i vanrednom stanju, njen zanačaj se

\footnotetext{
${ }^{46}$ Pravilnik o minimalnom broju vatrogasaca i tehničkoj opremi i obučenosti profesionalnih vatrogasnih jedinica (SI. glasnik Republike Srbije, br. 18/2012).

${ }^{47}$ Pravilnik o uslovima koje moraju ispunjavati pravna lica registrovana za izvođenje posebne obuke za lica koja rade na poslovima zaštite od požara (SI. Glasnik Republike Srbije, br. 92/2010, 86/2011).

${ }^{48}$ Pravilnik o sadržaju evidencije, načinu njihovog vođenja i periodičnosti pregleda pravnih lica svih kategorija ugroženosti od požara (SI. glasnik Republike Srbije, br. 87/2012-4).

${ }^{49}$ Odluka o određivanju ovlašćenih i osposobljenih pravnih lica za zaštitu i spasavanje u Republici Srbiji (SI. glasnik Republike Srbije, br. 36/2011).

${ }^{50}$ Odluka o osnivanju Budžetskog fonda za vanredne situacije (Sl. glasnik Republike Srbije, br. 92/2010).

${ }^{51}$ Nacionalna strategija zaštite i spasavanja u vanrednim situacijama (SI. Glasnik Republike Srbije, br. 86/2011).

${ }^{52}$ Strategija zaštite od požara za period od 2012-2017. godine (SI. glasnik Republike Srbije, br. 21/2012).

${ }^{53}$ Nacionalna strategija za zaštitu i spasavanje (SI. glasnik Republike Srbije, br. 86/11 od 18.11.2011).

${ }^{54}$ Ustav Republike Srbije (SI. glasnik Republike Srbije, br. 98/2006).

${ }^{55}$ Zakon o odbrani Republike Srbije (Sl. glasnik Republike Srbije, br. 116/2007, 88/2009, 88/2009 - dr. zakon, 104/2009 - dr. zakon i 10/2015).

${ }^{56}$ Strategija nacionalne bezbednosti Republike Srbije (SI. glasnik Republike Srbije, br. 88/2009).

${ }^{57}$ Strategija odbrane Republike Srbije (Sl. glasnik Republike Srbije, br. 116/07).
} 
ogleda i u činjenici da ona predstavlja teorijski okvir za upotrebu Vojske Srbije. Kroz dodeljene misije i zadatke, navedene u Doktrini Vojske Srbije, država jasno definiše svoja očekivanja i zahteve prema Vojsci na očuvanju mira i bezbednosti Srbije.

Međutim, Vojska Srbije, kao najvažniji subjekat sistema odbrane čija snaga, opremljenost i osposobljenost prepoznata je od institucija koje upravljaju sistemom nacionalne bezbednosti Republike Srbije sve više nalazi svoje mesto kroz treću misiju - podrška civilnim vlastima u suprotstavljanju pretnjama bezbednosti. Podrška civilnim vlastima u suprotstavljanju pretnjama bezbednosti ostvaruje se kroz pomoć civilnim vlastima u suprotstavljanju unutrašnjem ugrožavanju bezbednosti, terorizmu, separatizmu i organizovanom kriminalu i kroz pomoć civilnim vlastima u slučaju prirodnih nepogoda, tehničko-tehnoloških i drugih nesreća. Doktrinarnim rešenjima, navedenim u Doktrini predviđeno je da se delovi Vojske Srbije mogu biti stavljeni u pripravnost i upotrebljeni u slučaju proglašenja vanrednog stanja usled prirodnih i drugih nesreća i katastrofa, po odluci načelnika Generalštaba Vojske Srbije ili nadležnog starešine, a po posebnom ovlašćenju predsednika Republike. $^{58}$

Razmatrajući doktrinarna rešenja, koja ukazuju na ulogu podrške Vojske u neborbenim operacijama, može se zaključiti da ovakvo doktrinarno rešenje ne odgovara stvarnom stanju upotrebe Vojske Srbije u prethodnom periodu u operacijama suprotstavljanju neoružanim pretnjama bezbednosti koja se izvodi u slučaju prirodnih nepogoda, industrijskih i drugih nesreća i epidemija, već da Vojska Srbije u ovim operacijama je imala vodeću ulogu u prethodnom periodu, što zahteva izmenu doktrinarnih rešenja gde bi Vojska Srbije imala vodeću ulogu i u neborbenim operacijama, kao preduslov uspešnosti planiranja, pripremanja i izvođenje neborbenih operacija kao što je operacija podrške civilnim vlastima u suprotstavljanju neoružanim pretnjama bezbednosti koja se izvodi u slučaju prirodnih nepogoda, industrijskih i drugih nesreća i epidemija.

Doktrina operacija Vojske Srbije je dokument kojim se utvrđuju opšta opredeljenja i osnovni stavovi o operacijama Vojske Srbije u miru, vanrednom i ratnom stanju. U Doktrini operacija stavovi su definisani na osnovu karakteristika bezbednosnog okruženja, fizionomije oružanih sukoba, definisanih misija i zadataka Vojske Srbije, karaktera i sadržaja savremenih vojnih doktrina i dostignutog stepena razvoja Vojske Srbije. Takođe, u Doktrini su utvrđeni stavovi o osnovama doktrine operacija, združenom operativnom konceptu i fazama izvođenja operacija Vojske Srbije gde se operacije definišu kao: „skup borbenih i/ili neborbenih aktivnosti, pokreta i drugih akcija, koje se preduzimaju po jedinstvenoj zamisli radi ostvarivanja opšteg cilja različitog značaja. Izvode se samostalno, u saradnji sa drugim snagama odbrane, snagama zemalja partnera i snagama saveznika". ${ }^{9}$

Kao vrsta neborbenih operacija koje definiše Doktrina operacija jesu i Operacije podrške civilnim vlastima u suprotstavljanju neoružanim pretnjama bezbednosti „kaja se izvode se u slučaju prirodnih nepogoda, industrijskih i drugih nesreća i epidemija“. 60 Gde se cilj izvođenja operacija navodi da je podrška civilnim vlastima i stanovništvu radi zaštite i spasavanja života ljudi, materijalnih dobara i životne sredine. ${ }^{61}$

\footnotetext{
${ }^{58}$ Doktrina Vojske Srbije, Medija Centar „Odbrana”, Beograd, 2010. str. 23.

${ }^{59}$ Doktrina operacije Vojske Srbije, str. 19.

${ }^{60}$ Isto.

${ }^{61}$ Isto.
} 
Iz navedenog može se zaključiti da kao i u Doktrini Vojske Srbije i Doktrina operacija definiše borbene i neborbene operacije kao i operacije podrške civilnim vlastima u suprotstavljanju neoružanim pretnjama bezbednosti.

Doktrinom Kopnene vojske upotreba snaga u slučaju prirodnih nepogoda, tehničkotehnoloških i drugih nesreća ostvaruje se izvođenjem neborbenih operacija čiji je osnovni cilj pružanje podrške civilnim vlastima u suprotstavljanju ne vojnim pretnjama bezbednosti a podršku civilnim vlastima snage Kopnene vojske realizuju kroz određene neborbene aktivnosti i to: 1) evakuacija stanovništva; 2) distribucija osnovnih životnih namirnica; 3) obezbeđenje zdravstvenih usluga, i 4) pružanje pomoći u saniranju posledica elementarnih i tehničko-tehnoloških nesreća. ${ }^{62}$

Iz navedenog može se zaključiti da osnovni preduslovi za uspeh operacije podrške civilnim vlastima u slučaju prirodnih nepogoda jesu usklađenost doktrinarnih rešenja i neposredna saradnja i koordinacija sa državnim organima koji rukovode svim snagama na ugroženom području i upotreba potpuno osposobljenih i opremljenih jedinica Vojske.

\section{Umesto zaključka}

$\mathrm{Na}$ osnovu analize stanja elementarnih nepogoda i drugih stanja opasnosti u poslednjih sedam godina na teritoriji Republike Srbije bilo je ukupno 175.083 razna događaja od čega 134.686 požara, 13.620 tehničkih intervencija (spasavanja ljudi u saobraćajnim i drugim tehničko tehnološkim nezgodama, intervenisanje i saniranje akcidenata sa opasnim materijama i drugih nezgoda), može se zaključiti da podaci ukazuju na rast elementarnih nepogoda i drugih stanja opasnosti, što je očekivati rast elementarnih nepogoda i drugih stanja opasnosti i u narednom periodu u Republici Srbiji. Takođe, može se zaključiti da elementarne nepogode i tehničke i tehnološke nesreće predstavljaju pretnju koja ugrožava živote i imovinu građana Republike Srbije i time ugrožava ostvarivanje nacionalnih interesa u oblasti bezbednosti i vitalnih odbrambenih interesa Republike Srbije. Shodnom navedenom u cilju preventivnog delovanja urađena je procena ugroženosti teritorije Republike Srbije, karta rizika od elementarnih nepogoda što je značajan korak institucija Republike Srbije u preventivnom delovanju, kao to da su doneta normativna i strategijsko doktrinarnih dokumenata koja uređuju upotrebu Vojske Srbije u zaštiti i spasavanju u vanrednim situacijama.

Komparativnom analizom normativnih rešenja može se zaključiti da je normativno uređenje u Republici Srbiji uređeno i omogućavaju angažovanje Vojske Srbije u zaštiti i spasavanju u vanrednim situacijama, i time obezbeđuje ostvarivanje nacionalnih interesa u oblasti bezbednosti, koji su izraz vitalnih vrednosti i potreba građana, naroda i države i proizilaze iz najviših vrednosti koje su utvrđene Ustavom Republike Srbije u sprečavanju delatnosti kojima se ugrožava životi i imovina građana Republike Srbije, što nije slučaj kad je u pitanju uređenje strategijskih dokumenata koja regulišu upotrebu Vojske Srbije u zaštiti i spasavanju u vanrednim situacijama.

${ }^{62}$ Šerif, B.; Slavković, R.: Doktrinarna rešenja upotrebe rečne flotile u vanrednim situacijama, Vojno delo, br. 5/2016 . 
Komparativnom analizom strategijski i doktrinarnih rešenja može se zaključiti da Nacionalna strategija za zaštitu i spasavanje ${ }^{63}$ nije u saglasnosti sa Strategija nacionalne bezbednosti ${ }^{64}$ i Strategija odbrane Republike Srbije ${ }^{65}$ po sledećim pitanjima:

1) U Strategiji nacionalne bezbednosti ${ }^{66}$ posebno je istaknuto da ona predstavlja osnov za izradu strategijskih dokumenata u svim oblastima društvenog života i funkcionisanja državnih organa i institucija, radi očuvanja i zaštite bezbednosti građana, društva i države. ${ }^{67}$ Tako, da Nacionalna strategija za zaštitu i spasavanje ${ }^{68}$ ne proizilazi iz Strategija nacionalne bezbednosti. ${ }^{69}$

2) U Strategiji odbrane Republike $S_{r b i j e}{ }^{70}$ je istaknuto da misije i zadatke Vojske definiše Narodna skupština Republike Srbije u skladu sa ustavom i na osnovu neotuđivog prava Republike Srbije na individualnu i kolektivnu odbranu, saglasno članu 51. Povelje UN i osnovnim principima međunarodnog prava koji reguliše upotrebu sile. ${ }^{71}$ Misije i zadatke Vojske Srbije ${ }^{72}$ i misije i zadatke civilne odbrane ${ }^{73}$ iskazane su u Strategiji odbrane Republike Srbije. ${ }^{74}$ Nacionalnom strategijom za zaštitu i spasavanje ${ }^{75}$ je definisana vizija

\footnotetext{
${ }^{63}$ Nacionalna strategija za zaštitu i spasavanje (SI. glasnik Republike Srbije, br. 86/11 od 18.11.2011).

${ }^{64}$ Strategija nacionalne bezbednosti Republike Srbije (SI. glasnik Republike Srbije, br. 88/2009).

${ }^{65}$ Strategija odbrane Republike Srbije (SI. glasnik Republike Srbije, br. 116/07).

${ }^{66}$ Strategija nacionalne bezbednosti Republike Srbije (Sl. glasnik Republike Srbije, br. 88/2009)

${ }^{67}$ Isto, str. 33.

${ }^{68}$ Nacionalna strategija za zaštitu i spasavanje (SI. glasnik Republike Srbije, br. 86/11 od 18.11.2011).

${ }^{69}$ Strategija nacionalne bezbednosti Republike Srbije (SI. glasnik Republike Srbije, br. 88/2009).

${ }^{70}$ Strategija odbrane Republike Srbije (Sl. glasnik Republike Srbije, br. 116/07).

${ }^{71}$ Isto, str. 11.
}

${ }^{72}$ Misije Vojske Srbije su: 1) odbrana Republike Srbije od oružanog ugrožavanja spolja, 2) učešće u izgradnji i očuvanju mira u regionu i svetu, i podrška civilnim vlastima u suprotstavljanju pretnjama bezbednosti. Dodeljene misije Vojska Srbije realizuje izvršavanjem zadataka. Odbrana Republike Srbije od oružanog ugrožavanja spolja realizuje se kroz odvraćanje od oružanog ugrožavanja, odbranu teritorije i odbranu vazdušnog prostora. Učešće u izgradnji i očuvanju mira u regionu i svetu realizuje se učešćem u međunarodnoj vojnoj saradnji i učešćem u multinacionalnim operacijama. Podrška civilnim vlastima u suprotstavljanju pretnjama bezbednosti realizuje se kroz pomoć civilnim vlastima u suprotstavljanju unutrašnjem ugrožavanju bezbednosti, terorizmu, separatizmu i organizovanom kriminalu i kroz pomoć civilnim vlastima u slučaju prirodnih nepogoda i tehničkih i tehnoloških i drugih nesreća. Vojska obavlja i druge zadatke, na osnovu odluke Narodne skupštine Republike Srbije.

${ }^{73}$ Misije civilne odbrane su: 1) obezbeđivanje pretpostavki za funkcionisanje sistema odbrane, 2) zaštita i spasavanje, i 3) učešće u međunarodnim operacijama zaštite i spasavanja. Obezbeđivanje pretpostavki za funkcionisanje sistema odbrane realizuje se kroz sledeće zadatke: pripremu državnih organa, organa državne uprave, organa autonomnih pokrajina, organa jedinica lokalne samouprave, privrednih društava i drugih pravnih lica za funkcionisanje u miru i u ratnom i vanrednom stanju; obezbeđivanje uslova za život i rad građana u miru i u ratnom i vanrednom stanju; obrazovanje i odbrambeno osposobljavanje građana i koordinaciju aktivnosti sa ostalim institucijama značajnim za odbranu. Zaštita i spasavanje realizuju se kroz osmatranje i obaveštavanje, zaštitu i spasavanje ljudi, zaštitu i sklanjanje materijalnih dobara i očuvanje životne sredine. Nosioci realizacije zadataka zaštite i spasavanja su snage civilne zaštite. U aktivnostima zaštite i spasavanja angažuju se i jedinice Vojske Srbije pod uslovima propisanim zakonom. Učešće u međunarodnim operacijama zaštite i spasavanja ostvaruje se na osnovu međunarodnih i bilateralnih ugovora i sporazuma, kao i u skladu sa ukazanom potrebom za otklanjanje posledica prirodnih i tehničkih i tehnoloških katastrofa. Civilna odbrana realizuje i druge zadatke na osnovu odluka zakonodavnih i izvršnih organa vlasti Republike Srbije, autonomnih pokrajina i jedinica lokalne samouprave.

${ }^{74}$ Strategija odbrane Republike Srbije (SI. glasnik Republike Srbije, br. 116/07).

${ }^{75}$ Nacionalna strategija za zaštitu i spasavanje (Sl. glasnik Republike Srbije, br. 86/11 od 18.11.2011). 
i misija. „Vizija - razvijen, sveobuhvatan, efikasan i efektivan sistem za smanjenje rizika i posledica od elementarnih nepogoda i drugih nesreća integrisanim upravljanjem vanrednim situacijama u Republici Srbiji kojim se doprinosi povećanju bezbednosti i održivom razvoju u regionu, i Misija - stvaranje uslova za izgradnju društva otpornog na katastrofe razvojem integrisanog i efikasnog sistema za zaštitu i spasavanje u Republici Srbiji do 2016. godine“" ${ }_{76}$ A koje ne proizilaze iz Ustava Republike Srbije, ${ }^{77}$ Zakona o odbrani Republike Srbije, ${ }^{78}$ Strategije nacionalne bezbednosti ${ }^{79}$ a posebno ne iz Strategije odbrane Republike Srbije ${ }^{80}$ u delu koji se donosi na misije i zadatke civilne odbrane gde je zaštita i spasavanje definisana kao druga misija Civilne odbrane i gde se zaštita i spasavanje realizuju kroz osmatranje i obaveštavanje, zaštitu i spasavanje ljudi, zaštitu i sklanjanje materijalnih dobara i očuvanje životne sredine. Gde se ističe da su nosioci realizacije zadataka zaštite i spasavanja su snage civilne zaštite. ${ }^{81}$ Poseban deo Nacionalne strategije za zaštitu i spasavanje ${ }^{82}$ koji nije uskljađen sa Zakona o odbrani Republike Srbije, ${ }^{83}$ Strategijom nacionalne bezbednosti ${ }^{84}$ i Strategijom odbrane Republike Srbije ${ }^{85}$ jeste pitanje u Poglavlju Organizacija, upravljanje i procedure, gde se navodi u Nacionalnoj strategiji za zaštitu i spasavanje ${ }^{86}$ da saglasno Zakonu o vanrednim situacijama za odgovor na vanrednu situaciju odgovorne su snage zaštite i spasavanja koje čine štabovi za vanredne situacije, jedinice civilne zaštite, vatrogasno-spasilačke jedinice, policija, Vojska Srbije i drugi subjekti čija je redovna delatnost zaštita i spasavanje ili koji su opremljeni i osposobljeni za ovakvo reagovanje. Takođe, u Nacionalnoj strategiji za zaštitu i spasavanje ${ }^{87}$ navodi se da u slučaju proglašenja vanredne situacije usled prirodnih i drugih nesreća i katastrofa, delovi Vojske Srbije mogu biti stavljeni u pripravnost i upotrebljeni po odluci načelnika Generalštaba Vojske Srbije ili nadležnog starešine, a po posebnom ovlašćenju predsednika Republike. ${ }^{88} \mathrm{U}$ delu Resursi u Nacionalnoj strategiji za zaštitu $i$ spasavanje, ${ }^{89}$ navodi se da Ministarstvo odbrane i Vojska Srbije ne razvijaju posebne kapacitete za angažovanje na izvršenju zadataka zaštite i spasavanja, već u slučaju potrebe postojećim kapacitetima vrše podršku civilnim vlastima i nosiocima poslova zaštite i spasavanja. U poslovima zaštite i spasavanja iz Ministarstva odbrane i Vojske Srbije mogu se an-

\footnotetext{
${ }^{76}$ Isto.

${ }^{77}$ Ustav Republike Srbije (SI. glasnik Republike Srbije, br. 98/2006) .

${ }^{78}$ Zakon o odbrani Republike Srbije (Sl. glasnik Republike Srbije, br. 116/2007, 88/2009, 88/2009 - dr. zakon, 104/2009 - dr. zakon i 10/2015).

${ }^{79}$ Strategija nacionalne bezbednosti Republike Srbije (Sl. glasnik Republike Srbije, br. 88/2009).

${ }^{80}$ Strategija odbrane Republike Srbije (Sl. glasnik Republike Srbije, br. 116/07).

${ }^{81}$ Isto.

${ }^{82}$ Nacionalna strategija za zaštitu i spasavanje (SI. glasnik Republike Srbije, br. 86/11 od 18.11.2011).

${ }^{83}$ Zakon o odbrani Republike Srbije (SI. glasnik Republike Srbije, br. 116/2007, 88/2009, 88/2009 - dr. zakon, 104/2009 - dr. zakon i 10/2015).

${ }^{84}$ Strategija nacionalne bezbednosti Republike Srbije (SI. glasnik Republike Srbije, br. 88/2009).

${ }^{85}$ Strategija odbrane Republike Srbije (SI. glasnik Republike Srbije, br. 116/07).

${ }^{86}$ Nacionalna strategija za zaštitu i spasavanje (SI. glasnik Republike Srbije, br. 86/11 od 18.11.2011).

${ }^{87}$ Isto.

${ }^{88}$ Isto, str. 14.

${ }^{89}$ Nacionalna strategija za zaštitu i spasavanje (Sl. glasnik Republike Srbije, br. 86/11 od 18.11.2011).
} 
gažovati kapaciteti logističke podrške, vazduhoplovne, inženjerski sastavi i jedinica $A B H O{ }^{90}$ Što se zaključuje da Vojska Srbije angažuje kapacitete logističke podrške, vazduhoplovne, inženjerski sastavi i jedinica $A B H O$. U okviru saradnje ističe se Konvencije o prekograničnom efektu industrijskih udesa, Republika Srbija sprovodi saradnju sa Ekonomskom komisijom Ujedinjenih nacija za Evropu (UNECE), ${ }^{91}$ druge subjekte sistema zaštite i spasavanja Nacionalna strategija za zaštitu i spasavanje ${ }^{92}$ ne prepoznaje.

3) Analizom Nacionalne strategija za zaštitu i spasavanje ${ }^{93}$ može se zaključiti da osnov za donošenje sadržan je u Zakonu o vanrednim situacijama („Službeni glasnik RS“, broj 111/09). Pored zakonodavnog okvira, osnov za izradu Nacionalne strategije sadržan je i u drugim nacionalnim i međunarodnim dokumentima, navodi se u Nacionalnoj strategiji za zaštitu i spasavanje kao što su: „Nacionalni program za integraciju Republike Srbije u Evropsku uniju, Nacionalna strategija održivog razvoja, Strategija nacionalne bezbednosti Republike Srbije, ${ }^{94}$ Milenijumski ciljevi razvoja, koje su definisale članice Ujedinjenih nacija i Hjogo okvir za delovanje 2005-2015: Razvoj otpornosti nacija i zajednica na katastrofe. Osim navedenih, prilikom izrade Nacionalne strategije u obzir su uzete Strategija unutrašnje bezbednosti Evropske unije i Strategija Evropske unije za podršku smanjenju rizika od katastrofa u zemljama u razvoju“" ${ }^{\prime 95}$ ali ne i Ustavom Republike Srbije, ${ }^{96}$ Zakon o odbrani Republike Srbije, ${ }^{97}$ Strategiji nacionalne bezbednosti ${ }^{98}$ i Strategiji odbrane Republike Srbije. ${ }^{99}$ Tako, da osnov za donošenje Nacionalne strategije sadržan je u Zakonu o vanrednim situacijama („Službeni glasnik RS“, broj 111/09). U okviru saradnje ističe se Konvencije o prekograničnom efektu industrijskih udesa, Republika Srbija sprovodi saradnju sa Ekonomskom komisijom Ujedinjenih nacija za Evropu (UNECE).

Komparativnom analizom normativnih, strategijskih i doktrinarnih rešenja da u strategijskim i doktrinarnim rešenjima misije, zadaci Vojske Srbije su u delu dokumenata neprecizni i kao takvi ne pružaju resurse za pravovremeno reagovanje što može dovesti do nesagledivih poledica, posebno se to odnosi u delu treće misije Vojske Srbije „Podrška civilnim vlastima u suprotstavljanju pretnjama bezbednosti ostvaruje se kroz pomoć civilnim vlastima u suprotstavljanju unutrašnjem ugrožavanju bezbednosti, terorizmu, separatizmu i organizovanom kriminalu i kroz pomoć civilnim vlastima u slučaju prirodnih nepogoda, tehničko-tehnoloških i drugih nesreća“. ${ }^{101}$ Takva, strategijsko doktrinarna rešenja su "neprecizna“" ${ }^{102}$ i kao takva zahtevaju izmenu doktrinarnih rešenja gde bi Vojska

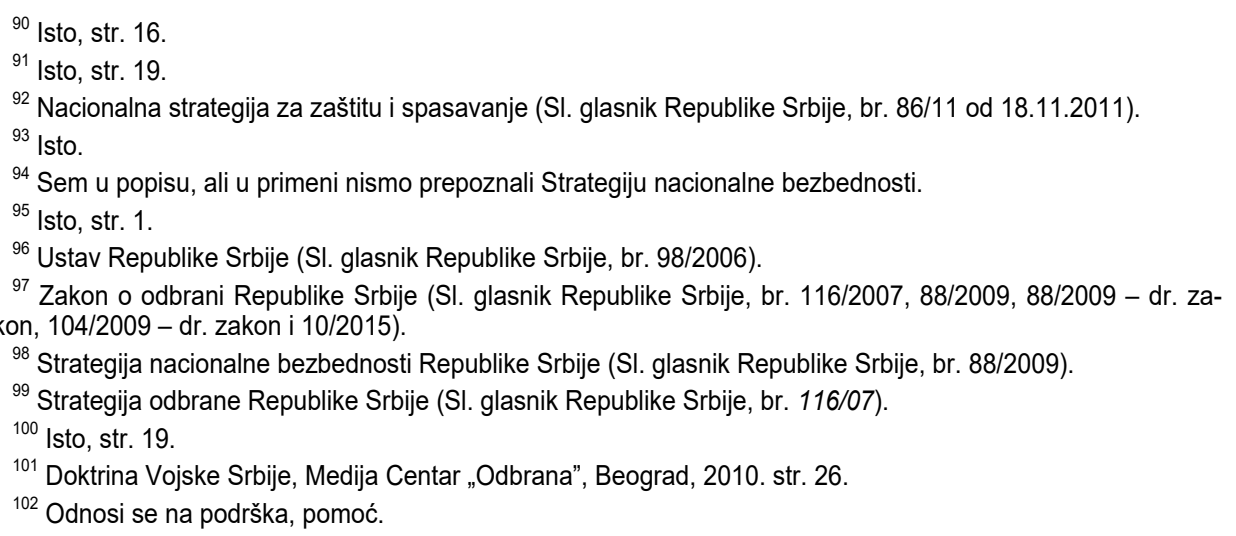


Srbije imala vodeću ulogu i u neborbenim operacijama, kao preduslov uspešnosti planiranja, pripremanja i izvođenja neborbenih operacija kao što je operacija podrške civilnim vlastima u suprotstavljanju neoružanim pretnjama bezbednosti koja se izvodi u slučaju prirodnih nepogoda, industrijskih i drugih nesreća i epidemija.

Mišljenja smo da je potrebno u strategijsko-doktrinarnim rešenjima izbaciti reč „podrška ${ }^{103 ", ~ „ p o m o c ́ ~}{ }^{104 ”,}$, čime bi se stvorili uslovi za učešće Vojske Srbije u podršci civilnim vlastima u suprotstavljanju pretnjama bezbednosti. To će omogućiti da Vojska Srbije planira i realizuje redovnu obuku i osposobljavanje sastava, jedinica i pojedinaca kroz svoje planove i programe obuke i osposobljavanja. Na taj način bi se postojeći resursi Vojske Srbije sačuvali i omogućilo Vojsci Srbije angažovanje punim kapacitetima, kada intenzitet pretnji i opasnosti to bude zahtevao, sve u cilju zaštite života i zdravlja građana Republike Srbije i njihove imovine.

Unapređenje upotrebe Vojske Srbije zaštiti i spasavanju u vanrednim situacijama, moguće je ostvariti kroz usklađivanje normativnih, strategijskih i doktrinarnih rešenja čime bi se obezbedilo unapređenje postojećeg koncepta obučavanja i osposobljavanja Vojske Srbije.

\section{Literatura}

[1] Decision No 1313/2013/EU of the European Parliament and of the Council of 17 December 2013 on a Union Civil Protection Mechanism, OJ L347/924.

[2] Doktrina Kopnene vojske.

[3] Doktrina operacije Vojske Srbije.

[4] Doktrina Vojske Srbije.

[5] Milanović A. i dr.: Poplave u Srbiji u periodu 1999-2009. godina - hidrološka analiza i mere zaštite od poplava, Glasnik srpskog geografskog društva, sveska 90, Beograd, 2010.

[6] Nacionalna strategija zaštite i spasavanja u vanrednim situacijama (SI. glasnik Republike Srbije, br. 86/11).

[7] Odluka o određivanju ovlašćenih i osposobljenih pravnih lica za zaštitu i spasavanje u Republici Srbiji (SI. glasnik Republike Srbije, br. 36/2011).

[8] Odluka o osnivanju Budžetskog fonda za vanredne situacije (Sl. glasnik Republike Srbije, br. 92/2010).

[9] Pravilnik o minimalnom broju vatrogasaca i tehničkoj opremi i obučenosti profesionalnih vatrogasnih jedinica, Sl. glasnik Republike Srbije, br. 18/2012.

[10] Pravilnik o načinu izrade i sadržaju plana zaštite od udesa (SI. glasnik Republike Srbije, br. 82/2012).

[11] Pravilnik o organizaciji i načinu upotrebe specijalizovanih jedinica civilne zaštite (SI. glasnik Republike Srbije, br. 26/2011).

[12] Pravilnik o organizovanju zaštite od požara prema kategoriji ugroženosti od požara (SI. glasnik Republike Srbije, br. 92/2011).

\footnotetext{
${ }^{103}$ Podržavati, -ážāvām nesvr. (nekoga, ređe nekome) a. Ugledati se na nekoga, povoditi se za nekoga (u ponašanju i sl.)... Rečnik Srpskog jezika, Matica srpska, Novi Sad, 2007. str. 952.

${ }^{104}$ Pomoć, pomoć, -ođi ž 1. a. radnja kojom se olakšava nečiji položaj ili rad... Rečnik Srpskog jezika, Matica srpska, Novi Sad, 2007. str. 970.
} 
[13] Pravilnik o sadržaju evidencije, načinu njihovog vođenja i periodičnosti pregleda pravnih lica svih kategorija ugroženosti od požara (Sl. glasnik Republike Srbije, br. 87/2012-4).

[14] Pravilnik o sadržaju informacija o opasnostima, merama i postupcima u slučaju udesa (SI. glasnik Republike Srbije, br. 18/2012).

[15] Pravilnik o uslovima koje moraju ispunjavati pravna lica registrovana za izvođenje posebne obuke za lica koja rade na poslovima zaštite od požara (Sl. glasnik Republike Srbije, br. 92/2010, 86/2011).

[16] Pravilnik o vrstama i količinama opasnih materija, objektima i drugim kriterijumima na osnovu kojih se sačinjava Plan zaštite od udesa i preduzimaju mere za sprečavanje udesa i ograničavanje uticaja udesa na život i zdravlje ljudi, materijalna dobra i životnu sredinu (SI. glasnik Republike Srbije, br. 8/2013).

[17] Strategija nacionalne bezbednosti Republike Srbije (Sl. glasnik Republike Srbije, br. 88/2009).

[18] Strategija odbrane Republike Srbije (SI. glasnik Republike Srbije, br. 116/07).

[19] Strategija zaštite od požara (SI. glasnik Republike Srbije, br. 21/12).

[20] Šerif, B.; Slavković, R.: Doktrinarna rešenja upotrebe rečne flotile u vanrednim situacijama, Vojno delo, br. 5/2016.

[21] Uredba o načinu angažovanja stvari za potrebe zaštite i spasavanja i načinu ostvarivanja prava na naknadu za korišćenje istih (SI. glasnik Republike Srbije, br. 10/2013).

[22] Uredba o razvrstavanju objekta, delatnosti i zemljišta u kategorije ugroženosti od požara (Sl. glasnik Republike Srbije, br. 76/2010).

[23] Uredba o sadržaju i načinu izrade planova zaštite i spasavanja u vanrednim situacijama (Sl. glasnik Republike Srbije, br. 8/2011).

[24] Uredba o sastavu i načinu rada štabova za vanredne situacije (SI. glasnik Republike Srbije, br. 98/2010).

[25] Uredba o sprovođenju evakuacije (SI. glasnik Republike Srbije, br. 22/2011).

[26] Vuruna M. i dr: Zaštita životne sredine, Medija centar "Odbrana", Beograd, 2012.

[27] Zakon o odbrani od grada (SI. glasnik Republike Srbije, br. 54/2015).

[28] Zakon o odbrani Republike Srbije (SI. glasnik Republike Srbije, br. 116/2007, 88/2009, $88 / 2009$ - dr. zakon, 104/2009 - dr. zakon i 10/2015).

[29] Zakon o otklanjanju posledica poplava u Republici Srbiji (Sl. glasnik Republike Srbije, br. 64/2015).

[30] Zakon o potvrđivanju Sporazuma između Vlade Republike Srbije i Vlade Ruske Federacije o osnivanju Srpsko-Ruskog humanitarnog centra (Sl. glasnik Republike Srbije, br. 6/2012).

[31] Zakon o potvrđivanju Sporazuma između Vlade Republike Srbije i Vlade Slovačke Republike o saradnji i uzajamnoj pomoći u vanrednim situacijama (Sl. glasnik Republike Srbije, br. 1/2012.

[32] Zakon o zaštiti od požara (SI. glasnik Republike Srbije, br. 111/2009, 20/2015). 